Jurnal Teknologi, 35(A) Dis. 2001: 1-8

(C) Universiti Teknologi Malaysia

\title{
THE RELEVANCY OF JUST-IN-TIME (JIT) CONCEPT IN GOVERNMENT PURCHASING
}

\author{
CHAI KHIN CHUNG ${ }^{1} \&$ NOOH ABU BAKAR ${ }^{2}$
}

\begin{abstract}
Just-in-Time (JIT) concept has been applied with considerable success in manufacturing environment. This paper provides insights of JIT concept and the pre-requisites for successful application of JIT in either private or public sectors. Although JIT concept has many advantages, a current study suggested that its application couldn't be applied in total to Government purchasing environment. Nevertheless, the essence of JIT concept in the context of supply management can and should be exploited.
\end{abstract}

\begin{abstract}
Abstrak. Aplikasi konsep "Just-in-Time" (JIT) telah mencapai kejayaan yang ketara dalam persekitaran pembuatan. Kertas kerja ini memberi penjelasan yang terperinci terhadap konsep JIT serta menerangkan prasyarat dalam pelaksanaannya di sektor awam atau swasta. Walaupun kekuatan konsep ini tidak dipertikaikan, tetapi terdapat kajian menunjukkan bahawa ia tidak sesuai digunapakai untuk perolehan kerajaan secara menyeluruh. Namun demikian, nilai-nilai konsep JIT dalam konteks pengurusan pembekalan boleh dan patut diterokai.
\end{abstract}

\subsection{INTRODUCTION}

The JIT concept was developed by Taiichi Ohno [1] of Toyota to improve Toyota's competitiveness in the global market and soon it was adopted by many Japanese industries. By early 1980s, many Western managers found themselves losing ground in the manufacturing "race" against the Japanese. Imai [2], liked many other Japanese, attributed the Japanese industrial success to the concept of JIT.

According to Pooler and Pooler [3], a common misconception of many managers in the eighties (and even today) is that JIT, in a narrow sense, was another planning tool that simply requires all the supplies to be shipped exactly as needed on time. In fact JIT has a much broader perspective than that understanding. It is a broad-based philosophy of management, which embraces everybody in the organization and covers every process towards a culture of never ending or continuous improvement by removing wastes and non-value-adding processes.

JIT purchasing is an integral part of the entire JIT manufacturing concept. In JIT manufacturing, inventory is seen as an evil, because it covers up quality problems and is costly to maintain. The essence of JIT purchasing is to purchase materials and

\footnotetext{
${ }^{1}$ The Royal Malaysia Police Headquarters, Bukit Aman

${ }^{2}$ Business Advanced Technology Centre, University Technology Malaysia (UTM).
} 
be "just-in-time" for consumption. And obviously, it also means that all these materials must be of high quality to enable smooth running of the system.

Is JIT concept applicable in government purchasing? If not the general JIT concept in total, is there any part of its philosophy that can be adopted? This paper presents some of the research findings related to the subject of interest.

\subsection{WHAT IS JUST-IN-TIME?}

JIT had many definitions, some of the common definitions are:

- A system that produces the required item at the time and in the quantities needed. [4]

- A manufacturing system where the parts that are needed to complete the finished products are produced or arrive at the assembly site as they are needed. [5]

- A philosophy that centers on the elimination of waste in manufacturing process. [6]

- An inventory control philosophy whose goal is to maintain just enough materials in just the right place at just the right time to make just the right amount of product. [7]

- The exact number of required units is brought to each successive stage of production at the appropriate time. [2]

It could be observed that all those definitions include either the term "manufacturing" or the reference to "making a product." However, JIT principles are also applicable in non-manufacturing environment. Pooler and Pooler [3] said, JIT is a combination of philosophy and process that needs time to implement and no two JIT programmes are exactly the same. A successful JIT programme involves total quality surveillance, JIT manufacturing techniques, and an involvement of people. JIT is a philosophy that crusades for the elimination of waste through the cooperative effort of everyone in the organization. JIT goals are consistent with normal inventory goals, but represent a tightening up philosophy. Distilled to its essence, JIT programes attempt to tighten the record keeping, and to carry minimum stocks by receiving frequent deliveries in smaller quantity. Receival is planned as close as possible to need, targeting at 100\% reliability. Perhaps perfection may not be attainable, but its pursuit is urged by striving to eliminate waste.

According to Giunipero and Keiser [8], JIT purchasing practices are characterized by a small supplier base whose firms:

(i) are located close to the buyer's plant,

(ii) make frequent deliveries, and

(iii) are considered long-term "partners" with the buying company. 
JIT calls for empowering employees and using their knowledge and experience to achieve quality at source. Treating employees with respect, keeping them informed, and motivating them to produce innovative ideas are the essential ingredients to achieve the goals of JIT. JIT is team approach based, including all parties involved in the internal process, suppliers and customers. JIT is hailed as creation of a flexible environment that keeps things simple (KISS - keep it short and sweet). JIT does not exist in isolation and it is not an island of excellence as it encompasses already proven techniques and programs that work well. It does not replace Material Resource Planning (MRP), Economy Order Quantity (EOQ), Enterprise Resource Planning (ERP), etc., rather, it emphasizes their proper execution.

\subsection{BENEFITS OF JUST-IN-TIME PURCHASING}

JIT purchasing has been defined by White [7] as "an inventory control philosophy whose goal is to maintain just enough material in just the right place at just the right time to make just the right amount of product". JIT purchasing concept can provide competitive advantages in manufacturing and service-orientated firms. One of the critical success factors of a manufacturing organization in producing quality products is its ability to acquire quality materials at the right time and with the right quantity. JIT requires close attention of its supply base and in-bound logistics. Giunipero and Keiser [8] found that JIT could bring improvement on internal and external communications, improve supplier performance, and warehouse space requirement reductions. Internal processes can be brought under control and focus should be on the extension on the application of JIT philosophy to its suppliers. This requirement had provided the foundation and urge for long-term partnership and strategic alliance.

The potential benefits of JIT in the area of purchasing identified by Schonberger and Ansari [9] included the following:

(i) Part Costs - Low scrap costs; low inventory carrying costs

(ii) Quality - fast detection and correction of unsatisfactory quality, and ultimately higher quality purchased parts

(iii) Design - fast response to engineering change requirements

(iv) Administrative efficiency - fewer suppliers; minimal expediting and order release work; simplified communications and receiving activities

(v) Productivity - reduced rework; reduced inspection; reduced parts-related delays

(vi) Capital requirements - reduced rework inventories of purchased parts, raw materials, work-in-progress and finished goods.

Except for (iii) above, all the other potential benefits are also relevant and desirous in government purchasing. However, those potential benefits are not easy 
Table 1 The Effect of JIT Purchasing Practice on Quality

\begin{tabular}{|l|l|l|}
\hline \multicolumn{1}{|c|}{$\begin{array}{c}\text { Purchasing } \\
\text { Activities }\end{array}$} & \multicolumn{1}{|c|}{ JIT Practice } & \multicolumn{1}{c|}{ Effect on Quality } \\
\hline Lot size & $\begin{array}{l}\text { Purchase in small lot-sizes with } \\
\text { frequent deliveries }\end{array}$ & $\begin{array}{l}\text { Fast detection and correction of } \\
\text { defects }\end{array}$ \\
\hline Supplier Evaluation & $\begin{array}{l}\text { Suppliers evaluated on ability to } \\
\text { provide high quality products }\end{array}$ & $\begin{array}{l}\text { Suppliers put more emphasis on } \\
\text { their product quality }\end{array}$ \\
\hline Supplier Selection & $\begin{array}{l}\text { Single source in close } \\
\text { geographical area }\end{array}$ & $\begin{array}{l}\text { Frequent on-site visits by technical } \\
\text { people; rapid and better under } \\
\text { standing of quality requirements }\end{array}$ \\
\hline Product Specification & $\begin{array}{l}\text { Fully specify only essential } \\
\text { product characteristics }\end{array}$ & $\begin{array}{l}\text { Suppliers have more discretion in } \\
\text { product design and manufacturing } \\
\text { methods, which results in specifica } \\
\text { tions that are more likely to be } \\
\text { attainable }\end{array}$ \\
\hline Bidding & $\begin{array}{l}\text { Stay with the same suppliers; } \\
\text { do informal value analysis to } \\
\text { reduce bid price; no annual } \\
\text { rebidding. }\end{array}$ & $\begin{array}{l}\text { Suppliers can afford cost of long- } \\
\text { term commitment to meet quality } \\
\text { requirements, and they become more } \\
\text { aware of buyer's true requirement }\end{array}$ \\
\hline Receiving Inspection & $\begin{array}{l}\text { Vendor certifies quality; receiving } \\
\text { inspections are reduced and } \\
\text { eventually eliminated }\end{array}$ & $\begin{array}{l}\text { Quality at source (the supplier) is } \\
\text { more effective and less costly }\end{array}$ \\
\hline Paperwork & $\begin{array}{l}\text { Less formal system; reduced } \\
\text { volume of paperwork }\end{array}$ & $\begin{array}{l}\text { More time available for purchasing } \\
\text { people to devote to quality matters }\end{array}$ \\
\hline
\end{tabular}

to realize as there are many constraints in government purchasing, which shall be elaborated later.

JIT purchasing has tremendous impact on quality. Schonberger and Ansari [9] had summarized 7 important aspects of JIT purchasing and their effect on product quality as shown in Table 1.

For service industries, beside some of the benefits mentioned above, other significant benefits would be the reduction or even the elimination of non-moving inventories used in maintenance, the reduction of slow-moving inventories, healthier financial management and more focused in the organization goals. Giunipero and Keiser [8] pointed out the following benefits could be reaped if JIT is practiced in service industry, the same benefits are found by Chai [10] to be applicable in government purchasing as well, they are:

- Increased customer satisfaction because of better quality and delivery reliability. 
- Improved profits through better management of material, resulting from lower inventory levels and reduced warehouse requirements.

- Improve relations with internal customers.

- Improved communication links with major suppliers resulting in a more productive relationship.

- Improved customer delivery reliability.

Under the JIT operating condition, buyer-supplier relation is built on a high degree of mutual trust and openness. Both the buyer and the supplier must share information and also protect its confidentiality. When entering into this type of relationship, it is important that the buyer select suppliers that have consistently exhibited high levels of quality and delivery reliability.

\subsection{GOVERNMENT PURCHASING}

Government purchasing is similar in many ways to purchasing in industrial organizations. Fearon et al. [11] had this comment on their similarities: The fundamental objective is to identify sources of needed materials and to acquire those items when needed, as economically as possible within accepted standards of quality. The function must be able to react quickly, effectively, and efficiently to requirements, the policies and procedures must conform to sound business practice... Purchasers utilize professional techniques and modern methods, and professional buyers and managers are employed to assure that the purchasing program fully supports their organizations' needs.

Notwithstanding the similarities, government purchasing has distinct differences with industrial purchasing in several aspects. Most significantly, government purchasing is a stewardship function where the hired employees spend the taxpayers' money to support their employers' intention to serve their clients - the taxpayers. Dobler et al. [12] found that the purchasing function in governments has become a regulated, yet open, process defined and controlled by innumerable laws, rules and regulations, judicial and administrative decisions, and policies and procedures. Government purchasing tends to be more transparent and open to public scrutiny while such information in industrial purchasing are very often kept as trade secrets. Another difference is that government generally purchases a much broader range of items in order to support a wider spectrum of services by a large number of departments.

Government institutions generally operate under authority granted to them by constitutional provisions, statues, and in the case of local government, ordinances. Government purchasing function is expected to perform multi-roles in supporting the organization goals. The following roles played by the purchasing function had been identified Dobler et al. [12]: 
- A supplier of a wide variety of goods and services to many departments and agencies, which, in turn, use those items to produce public services and support internal operations.

- A decision maker, which must strike the appropriate balance between quality, total cost, timeliness, control, accountability, and politics.

- A staff adviser, which assists management and line departments in developing budgets, planning projects, and making lease-or-buy and makeor-buy decisions.

- An implementer of socioeconomic policy, which often is on the front line of economic development for local, small, and disadvantaged business.

- A marketer of business opportunities and a provider of information and technical assistance, especially to small and disadvantaged business.

Although government purchasing assures high degree of free competition and equal opportunity for all interested parties, one of the inherited weaknesses identified by Zenz [13] is its inability to favour a deserving supplier who has performed exceptionally well. Incidentally, this factor works against the fundamental principles of JIT where good performers are given preference to enter long-term relationship.

\subsection{ISSUES IN IMPLEMENTING "JUST-IN-TIME" CONCEPT IN GOVERNMENT PURCHASING}

Although Giunipero and Keiser [8] had found that JIT purchasing is applicable in service-orientated firms in general, however, Chai [10] found that it has little application in Government purchasing environment. This is because:

(i) Though Government procurement is meant to generate the national economy, by itself, it is not a profit-making venture per se. It has a much wider perspective and carries the mission of assisting the restructuring of society.

(ii) One of the main features of JIT is the close collaboration between buyers and sellers. Schonberger and Ansari [9] reiterated, "Under JIT purchasing, the cost criterion is less dominant. Materials specifications are not so as rigid, and the suppliers are encouraged to be innovative in meeting the specified needs." They further said that, the buyers would tend to stay with the sellers; do informal value analysis to reduce bid price and no rebidding is necessary for further purchases. This shall resulted in better quality in goods since suppliers can afford cost of commitment to meet quality requirements, as they become more aware of buyer's true requirement. However Chai found that this aspect of JIT is in contrary to the principles of competitive 
bidding where most of the government procurements were based on. When competitive bidding is used as the primary sourcing technique, the lowest qualified bidder would normally get the job. Many other important criterions and good practices are sidelined or become non-issues.

(iii) Government has its social obligation to allow all the eligible bidders to participate in government procurement by means of competitive bidding. Government purchasing is based on the principles of competitive bidding and "lowest acceptable offer". Efforts to inculcating "long-term" relationship and sharing of confidential information with a few suppliers can be deemed as a practice of nepotism and cronyism.

(iv) Government budget, is an appropriation budget that establishes fixed dollar amounts to achieve the objectives of the organization for the period specified. Revenue sources of government are limited and fixed for selected periods. It depends on the abilities of the government to collect taxes and borrow. Thus, government spending is not market driven; expenditures cannot be based on changing demands proportionally because revenue collection do not vary in any kind of proportion with demands.

(v) In appropriation budgeting, the performance measurements used by managers tended to focus on efficiency rather than the effectiveness. Rayburn [14] stressed that due to appropriation concept, managers often focus more on spending resources than obtaining results. At year-end, managers are tempted to spend the appropriated amounts, even if not needed. Unfortunately, it is found that this budgeting concept encourages Managers to think incremental increases in budget preparation, rather than to consider the service offered. A cost/benefit relationship is usually not the basis of performance evaluation. Further more, failure to spend the allowable limits implies managers do not need this large an amount, leading to reduced budgets for future periods. As a result, management tends to spend the sum as soon as possible. In doing so, purchases are tended to be in bulk and infrequent purchases, which is contradicting with one of the principle of JIT - making frequent delivery.

(vi) As a result of the budgeting system, it has a "pushing" effect on Government procurement - pushed by the amount of money appropriated. As such, the focus is on money available, not market demands. Lysons [15] stressed that JIT is basically a "demand pull" system. The budgeting system is in the collision course with the fundamental principle of JIT. Therefore, when market demand is not the focus, then JIT delivery becomes a non-issue. 


\subsection{CONCLUSION}

Numerous researches had confirmed the usefulness and relevancy of JIT purchasing in manufacturing industries and its application in the private service industries is also well accepted. Although government service is a kind of service industries, government purchasing has many significant differences when compared to purchasing in the service industry of private sector. The benefits of JIT purchasing are many and could also be adopted for government purchasing to improve purchasing effectiveness.

It is evident that there are many restrictions that do not allow government purchasing to practice JIT principles per se. However, the approach to this subject should not be dogmatic and neither treating it as too simplistic. To improve the quality of government purchasing function, kaizen, which is the Japanese concept of continuous improving could be the answer; one must strive for continuous improvement and be innovative to achieve the goal of best value for money. After saying that JIT Purchasing is not applicable in government procurement in total; however, government purchasing can still practice the essence of JIT, i.e. inculcating and maintaining good practices to remove waste, improve work processes and improve supply chain effectiveness. In that perspective, it is found that JIT can also contribute strategically and has its legitimate place in government purchasing.

\section{REFERENCES}

[1] Hartley, J. R. 1981. The Word's Greatest Production Line: The Japanese View. Automotive Industries. 12: 553-61.

[2] Imai M. 1991. Kaizen. McGraw-Hill International Editions.

[3] Pooler, V. H. and D. J. Pooler. 1997. Purchasing and Supply Management. Chapman \& Hall, 184-89.

[4] Manoochehri. Suppliers and the Just In Time Concept. 16-21

[5] Crosby. The Just In Time Manufacturing Process. 21-34

[6] Brooks, R. 1985. MRP II: The Right Stuff for Just In Time. Manufacturing Systems. 3(1): 32

[7] White, L. 1985. JIT: What Is It And How Does It Affect DP? Computer World. 19(24A): 41-42

[8] Giuni pero, L. C. and E. F. Keiser. 1987. JIT Purchasing in a Non-Manufacturing Environment: A Case Study. Journal of Purchasing and Materials Management. Winter.

[9] Schonberger, R. J. and A. Ansari. 1984. Just-in-Time Purchasing Can Improve Quality. Journal of Purchasing and Materials Management. Spring.

[10] Chai, K. C. 1999. Unpublished MSc Dissertation - Development of an Optimal Procurement Model for Royal Malaysia Police Application.

[11] Fearon, H. E., D. W. Dobler and K. H. Killen. 1993. The Purchasing Handbook. $5^{\text {th }}$ ed., New York: McGraw-Hill, Inc. 819-820.

[12] Dobler, D. W. and D. N. Burt. 1996. Purchasing and Supply Management - Text and Cases. 6 ed., McGrawHill International Editions, 747.

[13] Zenz, G. J. 1994. Purchasing And The Management of Materials. $7^{\text {th }}$ ed., John Wiley \& Sons, Inc. p.350.

[14] Rayburn, L. E. 1996. Cost Accounting - Using a Cost Management Approach, Sixth Edition.

[15] Lysons, K. 1996. Purchasing. 4th ed., M\&E Pitman Publishing. 